\title{
АНАЛІЗ ЗМІН В НОРМАТИВНО-ПРАВОВОМУ РЕГУЛЮВАННІ СТАТУСУ ПЕНСІЙНОГО ФОНДУ УКРАЇНИ З МОМЕНТУ ЙОГО СТВОРЕННЯ
}

\begin{abstract}
Актуальність досліджуваної теми. Пенсійне забезпечення виступає гарантією непрацездатних громадян на матеріальну допомогу, яка, відповідно до ст. 46 Конституції України, має забезпечувати рівень життя не нижчий від прожиткового мінімуму, встановленого законом [1]. 3 такою метою, в Україні функціонує окремий орган виконавчої влади - Пенсійний фонд України. Разом з цим, ефективне функціонування останнім можливе лише за умови належного нормативно-правового регулювання його статусу, визначення обсягу компетенції та завдань.
\end{abstract}

Формулювання цілей статті (постановка завдання). Здійснення аналізу нормативно-правового регулювання статусу Пенсійного фонду України, починаючи 3 моменту його створення, як органу пенсійного забезпечення. При цьому, у даній статті не буде охоплено ті акти, які визначають процедуру призначення пенсійних виплат. Досліджувана тема охоплює лише ті законодавчі та інші акти, якими визначено статус Пенсійного фонду України як органу виконавчої влади.

Виклад основного матеріалу. Пенсійний фонд України (далі Фонд) - це одна з найпотужніших і найбільш розгалужених фахових структур в державі, завданням якої є всебічна діяльність щодо пенсійного забезпечення громадян України. Являючись установою з потужним фахово-кадровим потенціалом, яка постійно розвиваються і самовдосконалюється, Фонд здійснює накопичення та розподіл значних за обсягом грошових коштів [2].

Після проголошення незалежності України у серпні 1991 року та прийняття в листопаді цього ж року Закону України «Про пенсійне забезпечення» сформувалася законодавча база функціонування Пенсійного фонду нової незалежної держави. Статтею 8 зазначеного Закону було передбачено, що Пенсійний фонд України є самостійною фінансово-банківською системою і що Положення про Пенсійний фонд Украіни затверджується Кабінетом Міністрів України [3].

Свої витоки, як незалежного органу, Пенсійний фонд України бере 3 Постанови Кабінету Міністрів України «Про створення Пенсійного фонду України» від 28 січня 1992 р. № 39, згідно якої на виконання Постанови Верховної Ради України від 6 грудня 1991 р. «Про порядок введення в дію Закону України «Про пенсійне забезпечення» для державного управління фінансами пенсійного забезпечення в Україні створено на базі Українського республіканського відділення Пенсійного фонду СРСР Пенсійний фонд України з управліннями в Республіці Крим, областях, містах Києві та Севастополі. Разом з цим, вказаною Постановою затверджено Положення про Пенсійний фонд України, яким фактично визначено його статут як самостійної фінансово-банківської системи, що здійснює управління фінансами пенсійного забезпечення на всій території України. 
Головними завданнями Пенсійного фонду України зазначеним Положенням визначено наступні: забезпечення фінансування витрат на виплату пенсій відповідно до Законів України «Про пенсійне забезпечення», «Про статус і соціальний захист громадян, які постраждали в наслідок Чорнобильської катастрофи», пенсій військовослужбовцям i працівникам органів внутрішніх справ, допомоги на дітей, а також інших витрат, покладених чинним законодавством на Пенсійний фонд України; збір і акумуляція внесків, призначених для пенсійного забезпечення і виплати допомоги; здійснення розширеного відтворення коштів Пенсійного фонду України на основі принципів самофінансування; участь у фінансуванні державних, регіональних і обласних програм соціальної підтримки пенсіонерів, інвалідів, інших категорій населення та страхуванні здоров'я пенсіонерів через страхові компанії; організація міжнародного співробітництва у сфері пенсійного забезпечення, зокрема щодо виплати пенсій громадянам, які виїхали за межі України [4].

З 1994 року сталися значні зміни в історії Пенсійного фонду України: він був перетворений із самостійної фінансово-банківської системи на центральний орган виконавчої влади, наділений відповідними повноваженнями. Водночас було суттєво удосконалено організаційну структуру Фонду.

Статус Пенсійного фонду як центрального органу виконавчої влади було визначено Положенням про Пенсійний фонд України, затвердженим Постановою Кабінету Міністрів України «Питання Пенсійного фонду Украіни» від 01 червня 1994 р. № 345. Відповідно службових та посадових осіб Пенсійного фонду України та його органів визначено державними службовцями. Так, зазначеним Положенням визначено, що Пенсійний фонд Україн є центральним органом державної виконавчої влади, підвідомчим Кабінету Міністрів України. Пенсійний фонд здійснює управління фінансами пенсій- ного забезпечення. При цьому, обсяг покладених на Фонд завдань не змінений. Вказане Положення було чинним до 6 травня 2001 р., коли Постановою Кабінету Міністрів «Деякі питання Пенсійного фонду» № 466 визнано таким, що втратило чинність [5].

Водночас, Указом Президента України від 1 березня 2001 р. № 121/2001 затверджено Положення про Пенсійний фонд України, яким було визначено аналогічні положення щодо статусу Фонду, а саме зазначено, що Пенсійний фонд України $€$ центральним органом виконавчої влади, що здійснює управління фінансами пенсійного забезпечення, діяльність якого спрямовується і координується Кабінетом Міністрів України [6]. При цьому, обсяг завдань визначено дещо вужчий, однак до такого включено участь у формуванні та реалізації державної політики у сфері пенсійного забезпечення та соціального страхування. Зазначене свідчить про надання Фонду більшої значимості у сфері пенсійного забезпечення.

Важливу роль у розвитку Пенсійного фонду та його утвердженні як центрального органу виконавчої влади відіграла передача органам Фонду функцій з призначення та виплати пенсій, які раніше здійснювались органами соціального захисту населення [2].

Цей процес розпочався 1 січня 1999 року з експерименту у Львівській області (Указ Президента України «Про проведення у Львівській області експерименту з призначення та виплати пенсій органами Пенсійного фонду України» від 20.10.1998 року № 1156) i остаточно завершився 1 липня 2002 poky.

Базовим нормативно-правовим актом, який визначав статут Пенсійного фонду, стали прийняті 14 січня 1998 року Основи законодавства України про загальнообов'язкове державне соціальне страхування (Закон України від 14.01.1998 № 16/98-ВР), які визначають принципи та загальні правові, фінансові, організаційні засади загаль- 


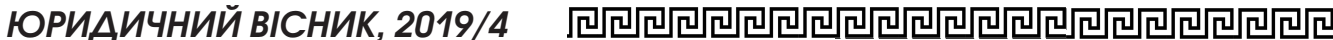

нообов'язкового державного соціального страхування громадян в Украіні. Стаття 6 цього Закону відносить Пенсійний фонд України до одного 3 видів суб'єктів загальнообов'язкового державного соціального страхування - страховиків, а також визначає, що страхові фонди беруть на себе зобов'язання щодо надання застрахованим особам матеріального забезпечення і соціальних послуг при настанні страхових випадків [7].

Слід зауважити, що Основи законодавства України про загальнообов'язкове державне соціальне страхування статтями 14-15 визначали в загальному вигляді адміністративно-правовий статус страхових фондів. Так, відповідно до статті 14 страхові фонди $€$ органами, які здійснюють керівництво та управління за визначеними законом видами загальнообов'язкового державного соціального страхування, провадять акумуляцію страхових внесків, контроль за використанням коштів, забезпечують фінансування виплат за загальнообов'язковим державним соціальним страхуванням та здійснюють інші функції згідно 3 затвердженими статутами.

Положення Основ законодавства України про загальнообов'язкове державне соціальне страхування визначають загальний правовий статус, який $€$ єдиним для всіх страхових фондів у сфері загальнообов'язкового державного соціального страхування, однак, адміністративно-правовий статус Пенсійного фонду України суттєво відрізняється, оскільки він, на відміну від інших фондів, вже був визначений як центральний орган виконавчої влади i, відповідно, як суб'єкт владних повноважень.

Таким чином, на початку 2000-х років відбувся процес формування нормативно-правової та організаційно-технічної бази пенсійної реформи. Пенсійний фонд України став потужною фінансовою та соціальною інституцією в державі, сформувалися його організаційний та кадровий потенціали.
Одним із основних етапів становлення статусу Пенсійного фонду, як незалежного органу влади, $€$ прийняття у 2003 році фундаментального для Фонду законодавчого акту, а саме Закону України «Про загальнообов'язкове державне пенсійне страхування».

Статтею 4 Закону України «Про загальнообов'язкове державне пенсійне страхування» від 09.07.2003 року № 1058-IV визначено, що Пенсійний фонд $€$ органом, який здійснює керівництво та управління солідарною системою, провадить збір, акумуляцію та облік страхових внесків, призначає пенсії та підготовляє документи для іï виплати, забезпечує своєчасне і в повному обсязі фінансування та виплату пенсій, допомоги на поховання, здійснює контроль за цільовим використанням коштів Пенсійного фонду, вирішує питання, пов'язані з веденням обліку пенсійних активів застрахованих осіб на накопичувальних пенсійних рахунках, здійснює адміністративне управління Накопичувальним фондом та інші функції, передбачені цим Законом і статутом Пенсійного фонду. Пенсійний фонд $€$ самоврядною неприбутковою організацією і здійснює свою діяльність на підставі статуту, який затверджується його правлінням. Пенсійний фонд набуває статусу юридичної особи з дня реєстрації статуту в спеціально уповноваженому органі виконавчої влади [8].

Вказані положення Закону України «Про загальнообов'язкове державне пенсійне страхування» свідчать про комплексність прийняття нормативно-правових актів стосовно статусу Пенсійного фонду України, оскільки можливість затвердження правлінням Фонду статуту визначена одночасно з прийняттям Постанови Кабінету Міністрів України від 24 червня 2003 р. № 960 «Про правління Пенсійного фонду».

Починаючи з 2007 року Пенсійному фонду України передано функції з призначення та виплати пенсій військовослужбовцям та іншим працівникам силових міністерств та відомств. Раніше їх 
пенсійне забезпечення здійснювалось 11 різними структурами [9].

24 жовтня 2007 р. Постановою Кабінету Міністрів України № 1261 затверджено Положення про Пенсійний фонд України, яким 3 урахуванням положень «Про загальнообов'язкове державне пенсійне страхування» одним з основних завдань Пенсійного фонду визначено керівництво та управління солідарною системою загальнообов'язкового державного пенсійного страхування [10].

Заключний період у нормативно-правовому регулюванні статусу Пенсійного фонду відзначається почерговістю прийняття декількох підзаконних актів, а саме Указу президента України «Про Положення про Пенсійний фонд України» від 06 квітня 2011 р. № 384/2011 (Указ втратив чинність на підставі Указу Президента України № 419/2019 від 20.06.2019), Постанови Кабінету Міністрів України «Про затвердження Положення про Пенсійний фонд України» від 23 липня 2014 р. № 280 (чинне на сьогодні).

Вказаними нормативно-правовими актами суттєво розширено обсяг компетенції Пенсійний фонд України як незалежного органу влади, що реалізує державну політику з питань пенсійного забезпечення $[11,12]$.

Здійснюючи аналіз підзаконних нормативно-правових актів, які регулюють діяльність Пенсійного фонду України, варто зауважити, що Положення про Пенсійний фонд України, затверджене Постановою Кабінету Міністрів України від 23 липня 2014 р. № 280, детально визначає адміністративно-правовий статус Пенсійного фонду Україн та належить до так званих «компетенційних» нормативно-правових актів. Слід відзначити, що на сьогодні це законодавчий акт, яким визначено елементи адміністративно-правового статусу Пенсійного фонду України відповідно до законодавства України та $з$ урахуванням реформування його компетенції і взаємодіi 3 іншими органами державної влади. Зокрема, пунктом 1 зазначеного Положення визначено, що Пенсійний фонд Украіни є центральним органом виконавчої влади, діяльність якого спрямовується i координується Кабінетом Міністрів України через Міністра соціальної політики, що реалізує державну політику з питань пенсійного забезпечення та ведення обліку осіб, які підлягають загальнообов'язковому державному соціальному страхуванню.

Пенсійний фонд України у своїй діяльності керується Конституцією та законами України, указами Президента України та постановами Верховної Ради України, прийнятими відповідно до Конституції та законів України, актами Кабінету Міністрів України, іншими актами законодавства (пункт 2 Положення).

Основними завданнями Пенсійного фонду України пунктом 3 Положення визначено такі: реалізація державної політики 3 питань пенсійного забезпечення та ведення обліку осіб, які підлягають загальнообов'язковому державному соціальному страхуванню; внесення пропозицій Міністрові соціальної політики щодо забезпечення формування державної політики із зазначених питань; виконання інших завдань, визначених законом.

На думку Балики Г.О., Положення про Пенсійний фонд України, затверджене постановою Кабінету Міністрів від 23 липня 2014 р. № 280, порівняно з Положенням про Пенсійний фонд України, затвердженим Указом Президента України від 06 квітня 2011 р. № 384/2011, є більш вдосконаленим за певними аспектами, хоча в цілому зазначені документи майже повністю дублюють один одного [13].

Висновки та узагальнення. Враховуючи зазначене, варто відмітити, що нормативно-правове регулювання статусу Пенсійного фонду України змінювалося в контексті загальних тенденцій та змін у країні. Разом із цим, вищевказані акти доволі часто дублюють положення один одного, що призводить до нормативного нагро- 


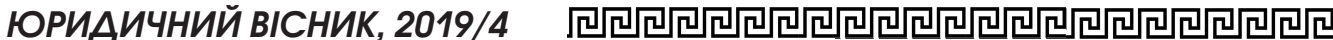

мадження без чіткої систематизації й визначення співвідношення актів між собою, а також пріоритетності один відносно одного. Вирішення цієі проблеми вбачається шляхом співпраці всіх гілок влади щодо визначення «єдиної політики» стосовно пенсійного забезпечення в загальному, та діяльності Пенсійного фонду України, як його частини, зокрема.

Статтю присвячено поетапному дослідженню базових нормативно-правових актів, якими визначено статус Пенсійного фонду України як иентрального органу виконавчоі влади у сфері пенсійного забезпечення. Зазначено, щзо Пенсійний фонд України є однією з найпотужніших $i$ найбільш розгалужених фахових структур в державі, завданням якої є всебічна діяльність щодо пенсійного забезпечення громадян України. Виступаючи установою з потужним фахово-кадровим потенціалом, яка постійно розвиваються $i$ самовдосконалюеться, Фонд здійснюе накопичення та розподіл значних за обсягом грошових коштів. Надано характеристику так званим «компетениійним» нормативно-правовим актам, які регламентують адміністративно-правовий статус Пенсійного фонду України. Проаналізовано проиес набуття Пенсійним фондом Украйни сучасних рис у контексті загальнонаціональних змін. Проаналізовані головні завдання Пенсійного фонду України, серед яких: забезпечення фінансування витрат на виплату пенсій відповідно до законодавства, допомоги на дітей; збір $i$ акумуляиія внесків, призначених для пенсійного забезпечення $i$ виплати допомоги; здійснення розширеного відтворення коштів Пенсійного фонду України на основі приничипів самофінансування; участь у фінансуванні державних, регіональних $i$ обласних програм соціальної підтримки пенсіонерів, інвалідів, інших категорій населення та страхуванні здоров'я пенсіонерів через страхові компанії; організація міннародного співробітництва у сфері пенсійного забезпечення, зокрема щодо виплати пенсій громадянам, які виіхали за межі України.

Констатовано про необхіність гармонізаціі нормативно-правових актів, якими визначено статус Пенсійного фонду Украӥни.

Ключові слова: Пенсійний фонд України, центральний орган виконавчої влади, пенсійне забезпечення, нормативно-правове регулювання.

Veselyi V. r ANALYSIS
OF STATUTORY
CHEGULATION
OFTHEPENSIONFUNDOFUKRAINE
SINCE ITS ESTABLISHMENT

The article is devoted to the phased research of basic normative and legal acts that define the status of the Pension fund of Ukraine as the central body of the executive power in the field of pension provision. It is noted that the Pension Fund of Ukraine is one of the most powerful and the most extensive professional structures in the country, whose task is comprehensive activity on pension provision of Ukrainian citizens. As an institution with strong professional and staffing potential that is constantly evolving and selfimproving, the Fund accumulates and distributes significant amounts of money. The description is given so-called "competent» normative and legal acts regulating the administrative and legal status of the Pension fund of Ukraine. The process of acquiring the Pension fund of Ukraine of modern traits in the context of national changes is analyzed.

The main tasks of the Pension Fund of Ukraine are analyzed, including: ensuring financing of expenses for payment of pensions in accordance with the legislation, child support; collecting and accumulating contributions intended for retirement benefits and benefits; implementation of extended 
reproduction of funds of the Pension Fund of Ukraine on the basis of selffinancing principles; participation in financing of state, regional and regional programs of social support for pensioners, persons with disabilities, other categories of population and health insurance of pensioners through insurance companies; organization of international cooperation in the field of pension provision, in particular in relation to the payment of pensions to citizens who have traveled outside Ukraine.

The necessity of harmonization of normative and legal acts determined by the status of the Pension fund of Ukraine is ascertained.

Key words: The Pension fund of Ukraine, Central executive authority, pension, normative and legal regulation.

\section{Література}

1. Конституція України. Відомості Верховної Ради України. 1996. №30. cm. 141

2. Історико-правовий аспект становлення Пенсійного фонду України. Актуальні проблеми права: теорія і практика. 2013. № 26. С. 311-319. /Електронний ресурс /. Режим достуny: http: / / nbuv.gov. ua / UJRN/app_2013_26_44.

3. Про пенсійне забезпечення: Закон України від 05.11.1991. Відомості Верховної Ради України. 1992. № 3. Ст.10.

4. Про створення Пенсійного фонду України: Постанова Кабінету Міністрів України; Положення від 28.01.1992 № 39. [Електронний ресурс]. Режим доступу: https: / / zakon.rada.gov.ua / laws / main $/ 39-92-\% D 0 \% B F$

5. Питання Пенсійного фонду: Постанова Кабінету Міністрів України від 01.06.1994 № 345. [Електронний ресурс].
Pежим docmyny: https://zakon.rada.gov. ua / laws / main / 345-94-\% D0\% BF.

6. Про Положення про Пенсійний фонд України: Указ Президента України; Положення від 01.03.2001 № 121/2001. [Електронний ресурс/.Режим доступу: https: / / zakon.rada.gov.ua/laws/show/121/2001.

7. Основи законодавства України про загальнообов'язкове державне соціальне страхування: Закон України від 14.01.1998 № 16/98-ВР /Електронний ресурс/. Режим доступу: https:// zakon.rada.gov.ua/laws/show/16/98$\%$ D0\% B2\% D1\% 80 / paran 153 .

8. Про загальнообов'язкове державне пенсійне страхування: Закон України від 09.07.2003 № 1058-IV. /Електронний peсурсl. Режим доступy: https://zakon. rada.gov.ua/laws/main/1058-15.

9. Історичні аспекти розвитку пенсійної системи, передумови та мета створення Пенсійного фонду. Офімійний веб-сайт Пенсійного фонду України. / Електронний ресурс /. Режим доступу: https: / / wrw.pfu.gov.ua/.

10. Про затвердження Положення про Пенсійний фонд України: Постанова Кабінету Міністрів України; Положення від 24.10.2007 № 1261. [Електронний ресурс]. Pежuм docmyny: https: / / zakon.rada.gov. ua/laws / main/1261-2007-\% D0\% BF.

11. Про Положення про Пенсійний фонд України: Указ Президента України; Положення, Перелік віة 06.04.2011 № 384/2011. /Електронний ресурс/. Режим доступy: https: / / zakon. rada.gov.ua/laws/show/384/2011.

12. Про затвердження Положення про Пенсійний фонд України: Постанова Кабінету Міністрів України; Положення від 23.07.2014 № 280. [Електронний ресурс]. Pежим docmyny: https: / / zakon.rada.gov. ua/laws / main / 280-2014-\% D0\% BF.

13. Балика Г. О. Адміністративно-правовий статус Пенсійного фонду України: дис. ... канд. юрид. наук: 12.00.07. Запоріжж, 2015. $221 \mathrm{c}$. 